\title{
Symptoms of depression and quality of life in functional dyspepsia patients
}

\author{
Muhammad Eko Cahyanto ${ }^{1 *}$, Neneng Ratnasari ${ }^{2}$, Agus Siswanto ${ }^{3}$ \\ ${ }^{1}$ Academic Hospital, Universitas Gadjah Mada, ${ }^{2}$ Division of Gastroenterology and \\ Hepathology, ${ }^{3}$ Division of Psychosomatic, Department of Internal Medicine, Faculty of \\ Medicine, Universitas Gadjah Mada/Dr. Sardjito General Hospital, Yogyakarta
}

\begin{abstract}
Dyspepsia is a common disorder characterized by heartburn, nausea, vomiting, bloating, feeling of fullness or early satiety, and belching. Functional dyspepsia (FD) or non-ulcer dyspepsia is a syndrome without any physical or endoscopic abnormalities underlying these symptoms. The impacts of FD on psychological disturbances and quality of life in patients have been postulated. However, it has not much been a concern. This study was conducted to evaluate the relationship between symptoms of depression and quality of life in patients with FD. This was an observational study with cross-sectional design involving 30 patients. The symptoms of depression were measured by beck depression inventory (BDI) and the quality of life of patients were measured by SF-36. The results showed that FD were more suffered consecutively by female patients $(66.7 \%)$, age over 45 years $(53.4 \%)$, housewives $(56.6 \%)$, educated graduates $(56.6 \%)$ and married $(90.0 \%)$. Moreover, patients who experienced symptoms of clinical depression with low, moderate and severe levels were $16.3 \%, 33.3 \%$ dan $10.0 \%$, respectively. A significant correlation between depressive symptoms and the overall of patients quality of life was observed $(r=0.481 ; p<0.05)$. Furthermore analysis showed that among eight domains of health in SF-36 analyzed, a negative significant correlation was observed between the depressive symptoms and the three domains of health i.e. general physical function, limitation of motion caused by physical problems, and vitality. In conclusion, there is a negative correlation between depressive symptoms and quality of life in patients with FD.
\end{abstract}

\section{ABSTRAK}

Dispepsia adalah suatu gangguan yang ditandai dengan nyeri ulu hati, mual, muntah, kembung, rasa penuh atau cepat kenyang, dan sendawa. Dispepsi fungsional atau dispepsi non ulkus adalah sindroma dyspepsia tanpa adanya kelainan fisik maupun endoskopik yang mendasari gejala tersebut. Pengaruh dispepsia fungsional terhadap gangguan psikologi dan kualitas hidup telah banyak diungkapkan. Namun belum banyak menjadikan perhatian. Penelitian ini dilakukan untuk mengkaji hubungan antara gejala depresi dan kualitas hidup penderita dispepsia fungsional. Penelitian ini merupakan penelitian obervasi dengan rancangan potong lintang yang melibatkan 30 penderita. Gejala depresi diukur dengan beck depression inventory (BDI) dan kualitas hidup penderita diukur dengan SF-36. Hasil penelitian menunjukkan dispepsia fungsional banyak diderita pasien wanita $(66,7 \%)$, umur di atas 45 tahun $(53,4 \%)$, ibu rmah tangga $(56,6 \%)$, pendidikan tinggi $(56,6 \%)$ dan sudah berkeluarga $(90,0 \%)$. Selanjutnya penderita yang mengalami gejala depresi klinik rendah, sedang dan berat berturut-turut adalah 16,3\%,33,3\% dan 10,0\%. Terdapat hubungan nyata antara gejala depresi dengan kualitas hidup penderita secara keseluruhan $(\mathrm{r}=$ $0,481 ; p<0,05)$. Analisis lebih lanjut membuktikan diantara 8 domain kualitas hidup yang dikaji, terdapat hubungan terbalik secara nyata antara gejala depresi dengan 3 domain kualitas hidup

\footnotetext{
$\overline{\text { * corresponding author: m.ekocahyanto@ugm.ac.id }}$
} 
yaitu fungsi fisik secara umum, keterbatasan gerak yang disebabkan oleh masalah fisik, dan vitalitas. Dapat disimpulkan terdapat hubungan terbalik antara gejala depresi dengan kualitas hidup penderita dispepsia fungsional.

Keywords : depression - quality of life - functional dyspepsia - SF-36 - BDI

\section{INTRODUCTION}

Dyspepsia is a common disorder that affects nearly a quarter of the general population in industrialized countries. It is one of the reasons people consult to doctors. ${ }^{1}$ Dyspepsia is a collection of symptoms or a syndrome consisting of heartburn, nausea, vomiting, bloating, feeling of fullness or early satiety, and hiccups. ${ }^{2}$ Functional dyspepsia (FD) or non-ulcer dyspepsia is a syndrome of dyspepsia without any physical or endoscopic abnormalities found underlying the symptoms. ${ }^{3-5}$ Functional dyspepsia is estimated to affect about $15 \%$ of the general population in western countries. ${ }^{4}$

Functional gastrointestinal disorders are not dangerous but very disturbing in daily activities and affect the quality of life significantly. This disorders causes a loss of social nature, either direct medical cost of doctor visits, diagnostic tests, and medications, as well as indirect costs due to absence at work or reduced work productivity. ${ }^{3,6}$ Based on data from various hospitals in Indonesia, FD frequencies ranges from $60-70 \%$ among patients who entered the department of gastroenterology-hepathology. ${ }^{7}$

The researches showed that there was a relationship between psychological disorders with dyspepsia. It is reported that $35 \%$ of FD patients were depressed. ${ }^{8}$ Depressed patients showed three times greater comorbidity with FD when compared to non-depressed patients. ${ }^{9}$ Functional dyspepsia impacts all main domains describing physical, mental and social aspects of health-related quality of life in the general population. ${ }^{10}$ Psychological disturbances influence the quality of life mostly in patients with dyspepsia in the form of emotional distress and the problem with the food and beverage intake. ${ }^{11}$ The purpose of this study was to evaluate the relationship between symptoms of depression and quality of life in FD patients.

\section{MATERIALS AND METHODS}

\section{Subjects}

This was an observational study with crosssectional design conducted on patients with FD in the Department of Internal Medicine, Dr. Sardjito General Hospital, Yogyakarta who fulfilled inclusion and exclusion criteria. The inclusion criteria were patients aged 21 years or older, had at least a primary school education and agreed to be the subject for research. Whereas the exclusion criteria were patients who had fever or had a history of jaundice or bleeding, used non-steroidal anti-inflammatory drugs, theophylline, digitalis, preparations of potassium/iron and alcohol, suffered from ischemic heart disease, collagen diseases and metabolic diseases such as diabetes, hypo/ hyperthyroidism, and disorders electrolyte, and suffered from severe mental disorders or difficulty in communication.

\section{Procedure of study}

Subjects who met the criteria were given an explanation concerning the background, objectives and benefits of the study. Subjects who willing to participate in this study were given an informed consents to be signed. The characteristics of subjects included name, age, gender, education level, address, occupation, 
marital status, and number of children were then recorded. Subjects underwent anamnesis and physical examination. Then, all subjects underwent assessment of quality of life by SF36 and symptoms of depression with the Beck Depression Inventory (BDI).

\section{Statistical analysis}

The correlation between symptoms of depression (BDI scores) and quality of life (SF36) was determined by Spearman test. Normality of data was assessed by Kolmogorov-Smirnov test. Multiple linear regression was used to assess influencing factors on quality of life by controlling other variables.

\section{RESULTS}

Thirty patients who diagnosed with FD and experienced psychosomatic symptoms of depression were involved in this study. The characteristics of the subjects are presented in TABLE 1 .

Further analysis using Spearman's rho correlation between depression symptoms (BDI) and quality of life (SF-36) is presented in TABLE 2. Among eight domains of health in SF-36 analyzed, three domains i.e. physical functioning, role limitations due to physical health, vitality (energy/fatigue) exhibited significantly correlation with depression symptoms $(p<0.01)$. Whereas, the other domains i.e. including general health, pain, social functioning, emotional well-being and role limitations due to emotional problems did not exhibited significantly correlation ( $\mathrm{p}>0.05)$.
TABLE 1. Characteristics of patients with FD with symptoms of depression

\begin{tabular}{|c|c|}
\hline Variables & $\mathrm{n}(\%)$ \\
\hline \multicolumn{2}{|l|}{ Sex } \\
\hline - Males & $10(33.3)$ \\
\hline - Females & $20(66.7)$ \\
\hline \multicolumn{2}{|l|}{ Age (Years) } \\
\hline - $<45$ & $14(46.6)$ \\
\hline - $\quad \geq 45$ & $16(53.4)$ \\
\hline \multicolumn{2}{|l|}{ Occupation } \\
\hline - Housewife & $17(56.6)$ \\
\hline - $\quad$ Public servants & $2(6.8)$ \\
\hline - $\quad$ Private & $8(26.8)$ \\
\hline - Others & $3(10.0)$ \\
\hline \multicolumn{2}{|l|}{ Level of education } \\
\hline - University Graduate & $13(43.4)$ \\
\hline - $\quad$ Post graduate & $17(56.6)$ \\
\hline \multicolumn{2}{|l|}{ Marital status } \\
\hline - $\quad$ Marriage & $27(90.0)$ \\
\hline - Single & $3(10.0)$ \\
\hline \multicolumn{2}{|l|}{ Symptoms of depression } \\
\hline - $\quad$ Mood disorder & $8(26.7)$ \\
\hline - Clinical depression & $5(16.3)$ \\
\hline - Depression & $10(33.3)$ \\
\hline - Major depression & $3(10.0)$ \\
\hline
\end{tabular}

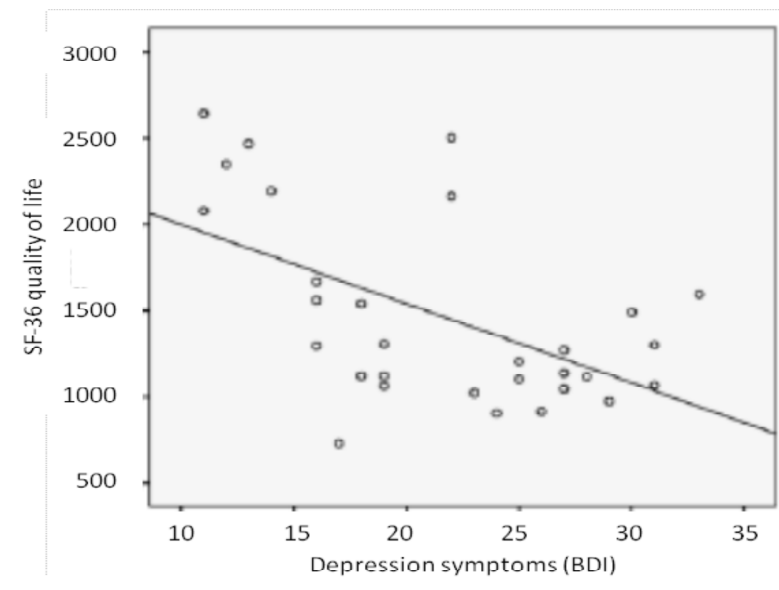

FIGURE 1. The correlation between depression symptoms (BDI) and the quality of life (SF-36) patients with FD 
TABLE 2. Test results of Spearman's rho correlation between depression symptoms (BDI) and quality of life (SF36) in patients with functional dyspepsia

\begin{tabular}{lcc}
\hline Variables & $\mathrm{R}$ & $\mathrm{p}$ \\
\hline Physical functioning & -0.509 & $0.01^{*}$ \\
$\begin{array}{l}\text { Role limitations due to physical health } \\
\text { Role limitations due to }\end{array}$ & -0.507 & $0.01^{*}$ \\
emotional problems & -0.437 & 0.05 \\
$\begin{array}{l}\text { Vitality (energy/fatigue) } \\
\text { General mental health (psychological }\end{array}$ & -0.517 & $0.01^{*}$ \\
distress/well being) & -0.193 & 0.5 \\
$\begin{array}{l}\text { Social functioning } \\
\text { Bodily pain }\end{array}$ & -0.303 & 0.5 \\
General health perceptions & -0.129 & 0.5 \\
\hline
\end{tabular}

\section{DISCUSSION}

Functional dyspepsia is the most common cause of dyspeptic symptoms. The prevalence of dyspepsia varies among different populations. It is influenced by the different definitions of dyspepsia as inclusion criterias, variation in survey population and environmental factors. A majority of patients suffering from significant levels of abdominal pain that interrupt daily activities and treatment remains unsatisfactory in this chronic condition. ${ }^{12}$ Epidemiologically, there were more women than men with FD. Education level of most patients with FD was university graduate $(56.6 \%)$. This is very interesting, because it shows that having a graduate degree does not necessarily guarantee that they work in an office, as most of the FD patients were housewives. The question arises whether the housewives feel a psychological burden as they do not fulfill the expectation of working professionally despite being a university graduate. This burden may have an impact on dyspepsia that they have. However, this is merely an assumption of the investigators. In addition, $90 \%$ of subjects were married. ${ }^{1,13}$
This study showed that most depressive symptoms that experienced by the FD patients was mood disorder (26.7\%), followed by clinical depression (20\%), depression (33.3\%) and major depression (10.0\%) (TABLE 1). These results indicated that the majority of FD patients experienced symptoms of depression. Previous studies reported that the chronically dyspepsia complaints significantly impacted on the quality of life, including daily activities, work, quality of sleep, social life, eating pattern, and emotional pressure. . $^{3,14,15}$

Among eight domains of health in SF-36 evaluated, three domains only (physical functioning, role limitation due to physical health, and energy/fatigue) showed a significant correlation with the FD symptoms of patients. However, other domains including general health, pain, social functioning, emotional wellbeing and role limitations due to emotional problems did not show a significant correlation (TABLE 2). It is indicated that there is an impairment of quality of life on FD patients who have depression symptoms. The impairment of physical function that limits their physical 
activity and the liminations in dealing with emotional problems cause the patients feel tired. However, it does not interfere the social function of the patients. Emotional conditions of the patients is actually good, although they have limintations that cause they may not able to solve emotional problems if it happened.

This study have limitations in exploring the mechanism of FD. Pathogenesis of fuctional dyspepsia is incompletely understood, although psychological disorders have been postulated to contribute. ${ }^{3,16}$ There is no clear whether psychological disorders trigger FD first or otherwise. Genetic factors in psychological disorders in patients with FD may be contributed in chronic dyspeptic symptoms of depression that will affect the quality of life of patients.

\section{CONCLUSION}

In conclusion, there is a negative correlation between depressive symptoms and quality of life in patients with FD. All patients with FD should be managed in a comprehensive intervention involving psychosomatic consultant, psychologist and gastroenterologist, so that the quality of life can be improved.

\section{ACKNOWLEDGEMENTS}

We would like to thank all patients who participated in this study. We also grateful to Head of Internal Medicine Department, Faculty of Medicine/Dr. Sardjito General Hospital, Universitas Gadjah Mada who has given his permission to conduct this study.

\section{REFERENCES}

1. McQuaid K. Dyspepsia. In: M Feldman, LS Friedman, MH Sleisenger. Sleisenger \& fordtran's gastrointestinal and liver disease: pathophysiology, diagnosis, management. $7^{\text {th }}$ edition. Philadelphia: Saunders, 2002:102-3.
2. Djojoningrat D. Dispepsia fungsional, dalam: dispepsia sains dan aplikasi klinik, FKUI. Jakarta. 2002: 20-25.

3. Talley NJ, Boyce P, Jones M. Dyspepsia and health care seeking in a community: how important are psycological factors? Dig Dis Sci. 1998; 43(5):1016-22.

4. Saad RJ, Chey WD (August 2006). Review article: current and emerging therapies for functional dyspepsia. Aliment Pharmacol Ther 2006; 24(3): 475-92.

5. van Kerkhoven LA, van Rossum LG, van Oijen MG, Tan AC, Laheij RJ, Jansen JB. Upper gastrointestinal endoscopy does not reassure patients with functional dyspepsia. Endoscopy 2006; 38(9): 879-85.

6. Li Y, Nie Y, Sha W, Su H. The link between social psychosocial and functional dyspepsia: an epidemiological study. Chin Med J 2002; 115(7): 1082-4.

7. Mujadid E. Permasalahan gangguan psikosomatik dalam ruang lingkup penyakit dalam, dalam: Simposium gangguan psikosomatik di bidang penyakit dalam, Medan: 2001;1-8.

8. Kane FJ, Strohlein J, Harper RG. Nonulcer dyspepsia associated with psychiatric disorder. South Med J 1993; 86(6):641-6.

9. da Silva RA, Pinheiro RT, da Silva RA, Horta BL, Moraes I, Faria AD. Functional dyspepsia and depression as an associated factor. Arq Gastroenterol 2006;43(4):293-8.

10. Aro P, Talley NJ, Agréus L, Johansson SE, BollingSternevald E, Storskrubb T, et al. Functional dyspepsia impairs quality of life in the adult population. Aliment Pharmacol Ther 2011; 33(11):1215-24.

11. Filipoviæ BF, Randjelovic T, Ille T, Markovic O, Milovanovic B, Kovacevic N, et al. Anxiety, personality traits and quality of life in functional dyspepsia suffering patients. Eur J Intern Med 2013; 24(1): 83-6.

12. Kumar A, Patel J, Sawant P. Epidemiology of functional dyspepsia. Supplement to JAPI 2012; 60: 9-12.

13. Wu JCY. Psychological co-morbidity in functional gastrointestinal disorders: epidemiology, mechanisms and management. J Neurogastro-enterol Motil 2012;18 (1):13-8.

14. Jones MP, Sharp LK, Crowell MD. Psychosocial correlates of symptoms in functional dyspepsia. Clin Gastroenterol Hepatol 2005; 3(6):521-8. 
15. Wu JCY. Psychological co-morbidity in functional gastrointestinal disorders: epidemiology, mechanisms and management. J Neurogastroenterol Motil 2012;18 (1):13-8.
16. Drossman DA. The functional gastrointestinal disorder and the rome II process. Gut 1999; 45:15 . 